\title{
Cultural Awareness, a Form of Risk Management in International Business: Case Study of China
}

\author{
Fadun Solomon Olajide \\ Glasgow School for Business and Society \\ Glasgow Caledonian University, Glasgow United Kingdom \\ E-mail: sofadun@yahoo.co.uk
}

Received: March 6, 2014 Accepted: March 22, 2014

doi:10.5296/ber.v4i1.5520 URL: http://dx.doi.org/10.5296/ber.v4i1.5520

\begin{abstract}
Mutual awareness of cultural references is essential in international business as levels of formality vary greatly among cultures. The emergence of capitalism into China induces international firms' investment in the country. This resulted to creation of a production base to explore the inexpensive factors of production, particularly low-cost labour. The study examines cultural awareness as a form of risk management in international business, using China as a case study. The study uses 'XYZ International', with western cultural background, as a hypothetical international business that operates in China market. The study explores international trade and global organisations; considers barriers to international business; outlines cultural awareness as a form of risk management in international business; highlights Chinese business culture; outlines the impact of culture on negotiation; appraises Chinese businessman culture and its impact in the Chinese market; and justifies reasons to support conducting trade with China. The study findings indicate that mutual awareness of cultural references is essential in international business, and levels of formality vary greatly among cultures. The implication for practice is that culture induces each country societal prevailing life-styles because culture and life-style influence patterns of consumption, manufacturing, agriculture, service, distribution and investment.
\end{abstract}

Keywords: Risk Management, International business, International organisations, Culture, Cultural awareness, International trade barriers, China

\section{Introduction}

Mutual awareness of cultural references is essential in international business as levels of 
formality vary greatly among cultures. Using China as a case study, the study examines cultural awareness as a form of risk management in international business. It uses a hypothetical international organisation (hereafter, XYZ International) that seeks to expand its business operations in China. XYZ International is an international business, with western cultural background, operating in China. The study explores international trade and global organisations; considers barriers to international business; outlines cultural awareness as a form of risk management in international business; highlights Chinese business culture; examines the impact of culture on negotiation; appraises Chinese business culture and its impact in the Chinese market; and justifies reasons to support conducting trade with China.

\section{Scope and Objectives of Study}

The study examines cultural awareness as a form of risk management in international business, using China as a case study. Specifically, objectives of the study include:

a) Description of international trade and global organisations;

b) Identification of barriers to international business;

c) Justification of cultural awareness as a form of risk management in international business;

d) Highlight Chinese culture and its impact on negotiation; and

e) Explore Chinese business culture and its impact in the Chinese market.

\section{Methodology}

Secondary data is the main source of information employed for the study. The study is a case study which explores relevant literature and international organisations data. International organisations data used for the study include: Central Intelligence Agency (CIA), Chinese Academy of Science, Science \& Technology in China (CASSTC); European Union (EU); Infoplease; Internet World Stats (IWS); International Monetary Fund (IMF); National Bureau of Statistics of China (NBSC); Organisation for Economic Co-operation and Development (OECD); PricewaterhouseCoopers; United Nations Development Programme (UNDP); United Nation Conference on Trade and Development (UNCTAD); World Bank (WB); and World Trade Organisation (WTO). The study findings obtained from through the literature and international organisations data are deemed sufficient to establish the role of cultural awareness in the international business. Moreover, to underpin the implication of the study findings for practice, China is used as a case study.

\section{Theoretical Framework and Literature Review}

\subsection{International Trade and Global Organisations}

International trade promotes openness thereby impacting national, regional and global economic growth. International business comprises of business transactions (including exchanges of money) necessary for production, transporting, and selling of goods and services across national borders (Guest et al., 2007; Alder, 2008; Czinkota et al., 2011). It is also referred to as international trade or foreign trade. International business consists of various 
forms of transactions undertaken across national borders to attain individuals, household, firms and organisations objectives. Types of international business include: export-import trade, direct foreign investment (wholly owned subsidiaries and joint ventures), licensing, franchising, and management contracts. International business can be undertaken in various ways. It includes: exporting goods and services; starting a joint venture with a company; license individuals or organisations to produce goods in the host country; opening branch networks for producing and distributing goods in the host country; and provision of managerial services to companies in the host country (Emerson, 2007; Nadeau and Casselman, 2008).

Global organisations are organisations which operate and compete in more than one country global business environment (Michie, 2011; Lechner, 2012). The global business environment is highly complex, uncertain and unpredictable. The global environment consists of forces and conditions that operate beyond an organisation's boundaries, but impact the organisational resources and operations (Ritzer, 2011; Stutz and Warf, 2011; Jones and George, 2013). The global business environment comprises of task environment and general environment. General environment consist of economic, technological, sociocultural, demographic, political, and legal forces which impact an organisation and its task environment; whilst, task environment consist of forces and conditions that originate with suppliers, distributors, customers, and competitors and affect an organisation's ability to obtain inputs and dispose of its outputs because they influence managers daily (Rath, 2012; Jones and George, 2013). Global environment has become highly competitive as a result of globalisation. Globalisation is a process driven by, and resulting from, increasing cross-border interaction and flow of goods, services, money, people, information, and culture (IMF, 2000; Guillen, 2001; Gangopadhyay and Chatterji, 2005; Lechner, 2012). Pearce and Robinson (2011:56) define 'globalisation refers to the strategy of approaching worldwide markets with standardized products' (Pearce and Robinson, 2011:56). Globalisation consists of forces which facilitate interaction of social, economic and political systems across cultures, countries and geographical regions (Michie, 2011; Lechner, 2012; Jones and George, 2013). It facilitates flow of four major forms of capital between countries: human capital, financial capital, resources capital and political capital (Ritzer, 2011; Lechner, 2012; Jones and George, 2013).

\subsection{Barriers to International Business}

Global organisations can use their worldwide experience to compete in global markets. Similarly, national, regional and international policies impact international trade. This is because a component of a nation's trade and investment policy impact on nations, firms, and individuals in the global business market. It is necessary to describe some terms commonly used in international trade: domestic trade/transaction; international transaction, import, export, trade surplus and trade deficit. Domestic trade is the selling of goods produced in the same country; and international trade involves production, transportation, and selling of goods and services across national borders. Imports are goods or services brought in a country from another country (e.g. made in Nigeria); while, exports are products or services produced in a country (e.g. China) and sold in another country (e.g. Nigeria). Trade surplus occurs when a country exports more goods than it imports; while, trade deficit occurs when a country imports more goods than it exports. International trade is regulated and promoted by a number of trade 
bodies, for example, World Trade Organisation (WTO). WTO is the main international organisation that deals with the rules of trade between nations. WTO provides a forum for negotiating agreements (legal and institutional frameworks) to minimise obstacles to international trade and ensure a level playing field for participants to contribute to global economic growth and development. There are two major benefits of reducing international trade barriers: enable businesses to sell their products and services in international markets at lower prices, as additional tariffs on exported products are reduced or eliminated; and increase competition thereby motivating firms to improve quality or reduce their prices in order to effectively compete with imported goods. However, a country can adopt barriers to international trade to protect its domestic businesses and consumers. Hence, barriers to international trade may be used to: encourage starting new domestic businesses; protect an existing industry that is struggling in a competitive global environment; protect consumers from importing products with problems; and ensure that imported products and services conform to the nation's safety standards (Wen-Cheng et al., 2011; Rath, 2012). Trade barriers a country can impose include: tariffs or custom duties - are form of tax on certain types of imports; non-tariff barriers - setting standard or quality of imported goods so high that foreign competitors cannot enter the market; increased costs of importing and exporting; excise taxes are taxes on manufacture, sale, or consumption of a particular product produced in the country; and currency fluctuations (Emerson, 2007; Gibson et al., 2012; Jones and George, 2013).

\subsection{Cultural Awareness, a Form of Risk Management in International Business}

The global market is dynamic; thus, risk is at the centre of international business activity. Although the degree of risk in international business varies among firms; awareness of culture of the host country is critical. Hubbard (2009:10) defines risk management process as 'the identification, assessment, and prioritisation of risks followed by coordinated and economical application of resources to minimise, monitor, and control the probability and/or impact of unfortunate events'. The study views cultural awareness in international business in the context of risk management. It perceives 'cultural awareness' as a form of risk management in international business which may impact, positive or negative, international organisations' operations (Damodaran, 2008; Hillson and Murray-Webster, 2011). Risk management does not eliminate risks, but it facilitates effective management of global organisations operations, thereby maximises opportunities and minimises threats. Basically, main stages of risk management, as shown in Figure 1, are: context analysis; risk identification; risk analysis; risk evaluation; risk treatment; monitoring and review; and communication and consulting. Furthermore, suitable risk management framework and adequate modus operandi are necessary to facilitate effective and efficient risk management in business enterprises (Fadun, 2013). Consequently, international businesses may undertake risk management in various ways; particularly, through mutual awareness and integration of cultural references into their strategic planning. 


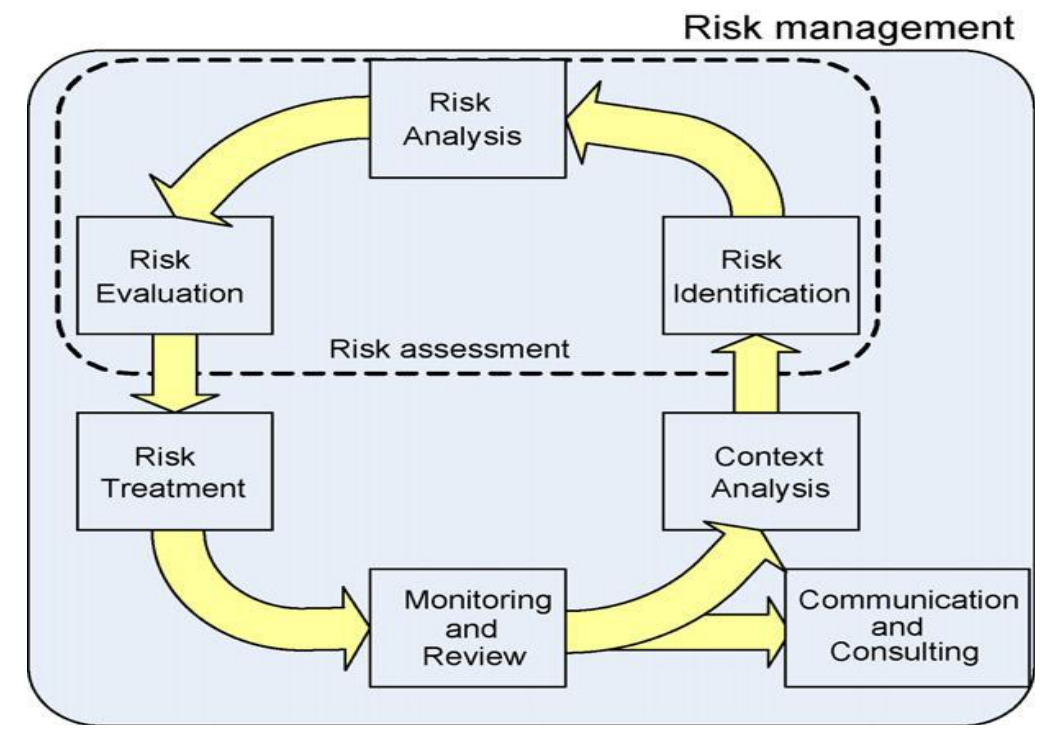

Figure 1: Stages of Risk Management

\subsection{Chinese Business Culture and its Impact in the Chinese Market}

The section considers some Chinese businessman customs, beliefs, culture and laws as well as their impacts on international business in Chinese market place. Knowledge and awareness of these customs, beliefs, culture and laws are critical in international trade because international organisations are undertaken across national borders. International organisations need to be awareness of host country culture to enable them use their worldwide market strategy approach and experience to compete effectively in global markets (Pearce and Robinson, 2011). Moreover, cultural outlook can be deciphered in terms of the changing global socio-economic context (Tibbs, 2011). Consequently, the culture of the host country significantly impacts international business firms' performance.

\subsubsection{Chinese Business Culture and its Impact on International Business in China}

Awareness of Chinese culture and negotiating components are key elements of establishing a successful gateway into the Chinese market (Horwitz et al., 2008). Culture entails complex construct that embodies a people's knowledge, morals, art, beliefs, customs, laws and other capabilities gathered by a community over time (Clifton, 2004). Czinkota et al. (2011:141) define 'culture as an integrated system of learned behaviour patterns that are characteristic of the members of any given society'. Similarly, Hofstede (2011:3) defines culture as 'the collective programming of the mind that distinguishes the members of one group or category of people from others'. Also, Hummel (2012) describes culture as collective experience of a society and its impact on reaction and decision-making in relation to every-day facts and circumstances. Culture is dynamic, continuously developing and evolving. Hence, culture entails much more than cultural dimensions, as culture manifests itself in several levels and domains (Leung et al., 2005). This implies that some cultural elements are stable, while others are dynamic and changing (Leung et al., 2005; Tibbs, 2011). According to Morden (2007) local cultures may be categorised into three: traditional, achieving and affluent. Traditional cultures are long-established cultures rooted in the past; achieving cultures are cultures that are 
gradually deviating from the traditions of the past to facilitate growth and development; and affluent cultures consist of industrial societies of North America, Europe, and South East Asia which place varied emphasis on various concepts and issues to protect those who are disadvantaged by the competitive nature of such cultures (Morden, 2007).

Culture induces countries societal prevailing life-styles because lifestyle influences cultural, behavioural, and social pattern of the society. This suggests that culture and life-style influence patterns of consumption, manufacturing, agriculture, service, distribution and investment (Morden, 2007; Czinkota et al., 2011; Tibbs, 2011). In essence, national culture shapes personal consumption thereby influences investment (political and economic) priority in manufacturing and distribution of consumer goods; as well as provision of auxiliary services. For XYZ International to succeed in China, the Chinese cultural difference must be considered and integrated in its operations so as enhance customers' trustworthiness in the firm. Geert Hofstede (1980), a Dutch social psychologist and management scholar, develops the most widely used framework for categorising national cultures. Similarly, Hofstede (2011) highlights six model dimensions of national cultures: power distance, uncertainty avoidance, individualism/collectivism, masculinity/femininity, long/short term orientation, and indulgence/restraint. Power distance relates to different solutions to the basic problem of human inequality; uncertainty avoidance relates to the level of stress in a society in the face of an unknown future; individualism versus collectivism focus on the integration of individuals into primary groups; masculinity versus Femininity deal with the division of emotional roles between women and men; long term versus short term orientation relate to the choice of focus for people's efforts, the future or the present and past; and indulgence versus restraint relate to the gratification versus control of basic human desires related to enjoying life (Hofstede, 2011:8). Considering difference in values, attitudes, and behaviour which characterises human interaction; managers must be aware of dynamic and complex environment of operating international business (Morden, 2007). The business environment in China is unique; hence, the knowledge of China business environment is necessary to ensure effectively operation and expansion of business in the country. To be locally responsive, international business managers' must adapt to local culture and legally mandated expectations (Palk and Sohn, 2004; $\mathrm{Wu}, 2008)$. Lack of local responsiveness and strategic planning are some of the major challenges of international businesses in China (Fan et al, 2009; Rath, 2012). Consequently, XYZ International managers' in China need to be aware and understand issues such as national geography and history; local political and economic management; international trade and competition policy; knowledge and technological development; socio-cultural features; and the international context within which the country may be placed.

\subsection{Chinese Business Culture}

There are three major intertwined determinants of Chinese business culture and negotiating style. They are: (1) Confucianism, Taoism, and War Stratagems - the backbone of Chinese business culture; (2) Guoqing - the milieu in which Chinese business culture evolved; and (3) adoption of International Best Practices - reform of Chinese business culture (Fang, 2006; Sebenius and Qian, 2008; Wu, 2008). 
4.5.1 Confucianism, Taoism, and War Stratagems: Cores of Chinese Business Culture

\subsubsection{Confucianism}

Confucianism is an ethical belief system, rather than a religion, which deals with human relationships based on the teachings and writing of the philosopher Confucious. From Chinese business culture and negotiating style perspective, confucianism entails six core values: moral cultivation; importance of interpersonal relationships; family orientation; respect for seniority and hierarchy; pursuit of harmony and avoidance of conflict; and the concept of face (Fang, 1999; Fang, 2006; Sebenius and Qian, 2008). In essence, Confucianism emphasises the need for people to trust each other, to avoid conflict and to promote harmonious co-existence (Ghauri and Fang, 2001). Confucianism places great value on interpersonal relationships (Fang, 1999); and encourages respect for hierarchy and status (Miles, 2003). Operations in China where Confucianism advocates for individual connections rather than the rule of law have been problematic. Business ethics have not been adhered to, making the firm lose out on opportunities for lack of connections, referred to as Guanxi (Goodrich, 2005). In individualistic societies, competition for resources is the norm where each person tends to focus on his or her own self-interest; hence, such societies preferred individualism over group conformity (Emerson, 2007). Due to the influence of Confusion, Chinese would rather trust people more than any other contracts during the business transactions (Dunfee and Warrant, 2001). Hence, to successfully expand in the Chinese market, XYZ International must adopt people oriented approach and maintain high level of trust relationship with Chinese partners and customers (Ghauri and Fang 2001; Graham and Lam, 2003: Wu, 2008).

\subsubsection{Taoism}

Taoism deals with creativity of life and harmony with nature (Fang, 2001). Tao (pronounced 'Dow') simply implies the path or the way; meaning the general law of nature between two changing forces, the negative and the positive, of the same phenomenon (Fang, 1999). Hence, Chinese believe that Tao regulates natural occurrences and nourishes balance in the Universe. It embodies the harmony of opposites; and encompasses the power which envelops, surrounds and flows through all things, living and non-living (Tian, 2007). It indicates that people's fortune and business performance are impacted by their environment; and more importantly, the position of building relative to its physical environment, interior layout and arrangement of furniture can influence events occur to the occupants of the building (Tsang 2004). Consequently, Taoism philosophy traditions would influence business behaviour and decision-making of XYZ International in the Chinese market (Wu, 2008).

\subsubsection{Stratagems}

The third backbone of Chinese business culture is Chinese Stratagems, or Ji (Fang, 1999; Von Senger, 2006). The Chinese stratagems is a strategic component of Chinese culture and thinking which characterised the strategic patterns of Chinese negotiating style and Chinese negotiating tactics (Mun, 1990; Chu, 1991; Tung, 1994; Chen, 1995; Faure, 1998; Fang, 1999: Von Senger, 2006). The Chinese belief that business is a marketplace and the marketplace is a battlefield (Chu, 1991). Sun Tzu, a Chinese military strategist in the period of warring state (c. 
300 BC), in his book The Art of War critically examines Chinese thinking about stratagems (Sun, 1982). Furthermore, Von Senger explores the Thirty-Six Stratagems principles which underlined the Chinese wisdom in dealing with enemies, and overcoming difficult and dangerous situations (Von Senger, 1991). Moreover, Guari and Fang (2001) emphasise that Chinese stratagems ( $\mathrm{ji}$ ) is more than a list of strategies, tricks and ploys; rather is a collection of Chinese wisdom and a framework through which challenging situations can be assessed and addressed. In other words, Chinese stratagems advocate the application of human wisdom to handle situations and to gain advantage over the opponent rather engaging in physical battle. For example, the Chinese businessmen will typically not force international business partners to accept their terms, instead persuade partners by signal that competitors are ready to offer better terms. Consequently, XYZ International managers should be aware that Chinese businessmen are more likely to apply stratagems when dealing with people they do not trust.

\subsection{Guoqing-The Milieu in Which Chinese Business Culture Evolved}

Guoqing refers to distinctive and dynamic elements of contemporary socio political system and conditions of the People's Republic of China (PRC) after opening up its economy to the rest of the world in 1978 (Ghuari and Fang, 2001; Fang, 2006; Sebenius and Qian, 2008). China is a socialist state and Chinese politics influence every aspects of Chinese life, including business. Guoqing comprises eight variables: (1) Chinese politics; (2) China's socialist planned (centralised) economic system; (3) legal framework - China's legal system is influenced greatly by human factors and ideology; (4) technology advancement; (5) great size - world largest population; (6) China backwardness and uneven development; (7) rapid change; and (8) Chinese bureaucracy (Ghuari and Fang, 2001: Fang, 2006). These guoqing variables immensely influenced Chinese business culture; hence, XYZ International managers' must be aware of these variables and how they impact on business activities in the Chinese market place.

\subsection{Adoption of International Best Practices - Reform of Chinese Business Culture}

Following Deng Xiaoping's open door policy, China has increasingly integrated into the world economy and international politics. From December 1978 China gradually abandon planning system and adopted a more market oriented economy; thus, gradually relaxed its social and ideological controls. The major reasons for China market oriented reform include: unpopularity of the cultural Revolution of 1966-1976; challenges and economically inefficient of planning system; and rapid economic growth and development in more market-oriented neighbouring economies, including Hong Kong, Taiwan, South Korea and Singapore (Chow, 2004). Moreover, China's economic reform success can be measured partly by its rapid economic growth in real GDP (about 9.6 percent) in three decades after 1978 (World Bank, 2013). Furthermore, three basic factors accounted for the success: first, Chinese citizens' freedom and opportunity to make money by hard working and ingenuity in a healthy competitive environment; second, large amount of human capital imbedded in the Chinese culture; and third, political will and competence of Chinese leaders in carrying out economic reform (Chow, 2004). The western exposures have impacted Chinese business culture in that western technology, lifestyle, value and business rules are gradually influencing the mentality 


\section{Macrothink}

Business and Economic Research

ISSN 2162-4860

2014, Vol. 4, No. 1

and behaviour of the Chinese (Sebenius and Qian, 2008; Tisdell, 2009).

\subsection{The impact of Culture on Negotiation}

Western and Chinese negotiation approaches often appear incompatible and these differences stem from their cultural backgrounds. The westerners (e.g. American) perceive Chinese negotiators as inefficient, indirect, and dishonest; while the Chinese perceive American negotiators as aggressive, impersonal, and excitable (Graham and Lam, 2003). Meanwhile, Salacuse (2004) identifies ten most important cultural factors which influence business negotiations, as indicated below.

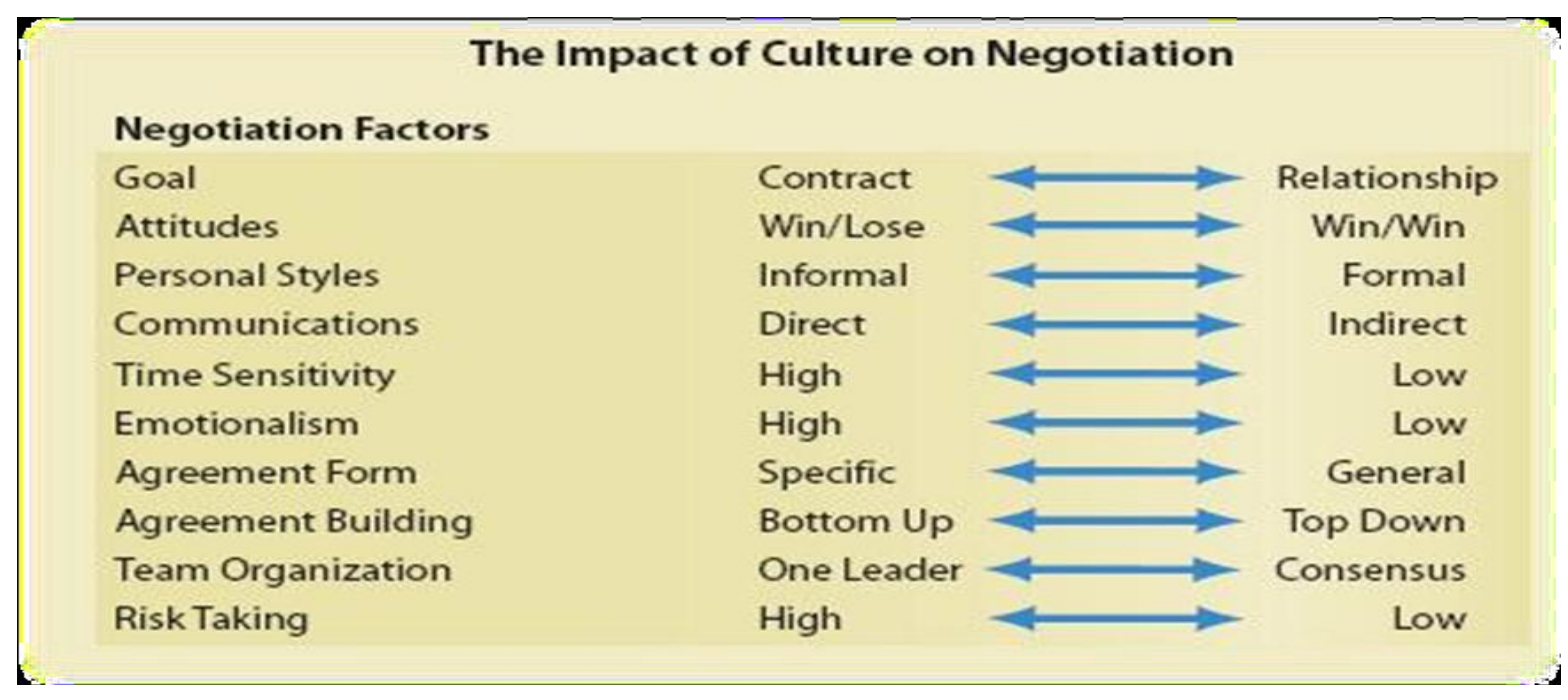

Source: Salacuse (2004)

Similarly, Graham and Lam (2003) present negotiating view from both sides (American and Chinese), as summarised below.

\begin{tabular}{|l|l|}
\hline AMERICAN & CHINESE \\
\hline THEIR BASIC CULTURAL VALUE AND WAYS OF THINKING \\
\hline Individualist & Collectivist \\
\hline Egalitarian & Hierarchical \\
\hline Information oriented & Relationship oriented \\
\hline Reductionist & Holistic \\
\hline Sequential & Circular \\
\hline Seeks the truth & Seeks the way \\
\hline The argument culture & The haggling culture \\
\hline \multicolumn{2}{|c|}{} \\
\hline HOW THEY APPROACH THE NEGOTIATION PROCESS \\
\hline \multicolumn{2}{|c|}{ Non-task Sounding } \\
\hline Quick meetings & Long courting process \\
\hline
\end{tabular}




\begin{tabular}{|l|l|}
\hline Informal & Formal \\
\hline Make cold calls & Draw on intermediaries \\
\hline \multicolumn{2}{|c|}{ Information Exchange } \\
\hline Full authority & Limited authority \\
\hline Direct & Indirect \\
\hline Proposals first & Explanations first \\
\hline \multicolumn{2}{|c|}{ Means of Persuasion } \\
\hline Aggressive & Questioning \\
\hline Impatient & Enduring \\
\hline \multicolumn{2}{|c|}{ Terms of Agreement } \\
\hline \multicolumn{2}{|c|}{} \\
\hline Forging a 'good deal' & Forging a long-term relationship \\
\hline
\end{tabular}

Adapted from: Graham and Lam (2003)

\subsection{Arguments to Support Conducting Trade with China}

China's deepening reform and opening up are induced by the country's growing wealth, ageing population, rising environmental awareness, changing consumer attitudes, greater mobility, urbanisation, and decreasing household sizes (PricewaterhouseCoopers, 2013). We now proceed to identify and discuss reasons or arguments for conducting trade with China.

\subsubsection{China Modernisation and Technology Advancement}

China modernisation and technology advancement are good reasons for conducting trade with China. Innovative technological development has gradually become essential part of modernisation (Irrgang, 2007); and China scientists pay great attention to development trends of science and technology in the world (Jin, 2012). Advanced technology induces highest degree of automation and rationalisation. Technological advancement has transformed China into one of the largest high-tech exporting country in the world (UNDP, 2001). Similarly, technology advancement contributed greatly to China business advancement and modernisation (CASSTC, 2009). China is the leader in the world in both importing and exporting of information and communication technology (ICT) products, including: computers, smart phones and tablets (UNCTAD, 2012). China imported more than $\$ 280$ billion and exported more than $\$ 459$ billion of ICT goods in 2010 (Tables 1 and 2), ahead of the United States (UNCTAD, 2012). 
Table 1. Top 20 exporters and importers of ICT goods, 2009 and 2010 (Millions of dollars and percentage)

\begin{tabular}{|c|c|c|c|c|c|c|c|}
\hline Exporter & $\begin{array}{l}\text { ICT goods } \\
\text { exports in } \\
2009\end{array}$ & $\begin{array}{c}\text { ICT } \\
\text { goods } \\
\text { exports } \\
\text { in } 2010 \\
\end{array}$ & $\begin{array}{c}\text { Share of } \\
\text { world } \\
\text { ICT } \\
\text { goods } \\
\text { exports } \\
2010\end{array}$ & Importer & $\begin{array}{c}\text { ICT } \\
\text { goods } \\
\text { imports } \\
2009\end{array}$ & $\begin{array}{c}\text { ICT } \\
\text { goods } \\
\text { imports } \\
2010\end{array}$ & $\begin{array}{c}\text { Share of } \\
\text { world } \\
\text { ICT } \\
\text { goods } \\
\text { imports } \\
2010\end{array}$ \\
\hline China & $356: 301$ & 459.522 & $26.70 \%$ & China & $220: 214$ & 284783 & $15.30 \%$ \\
\hline $\begin{array}{l}\text { Hong Kong, } \\
\text { China }\end{array}$ & $141: 881$ & 176.964 & $10.30 \%$ & $\begin{array}{l}\text { United } \\
\text { States }\end{array}$ & $230 \times 627$ & $280^{\circ} 074$ & $15.00 \%$ \\
\hline $\begin{array}{l}\text { United } \\
\text { States }\end{array}$ & $113 * 157$ & $134: 549$ & $7.80 \%$ & $\begin{array}{l}\text { Hong Kong, } \\
\text { China }\end{array}$ & $149 \cdot 537$ & 188736 & $10.10 \%$ \\
\hline Singapore & 91.442 & $120 \% 806$ & $7.00 \%$ & Germany & $78: 522$ & 97728 & $5.30 \%$ \\
\hline $\begin{array}{l}\text { Republic of } \\
\text { Korea }\end{array}$ & $79: 508$ & $99^{\prime} 884$ & $5.80 \%$ & Singapore & $66^{*} 033$ & 86.561 & $4.70 \%$ \\
\hline $\begin{array}{l}\text { Taiwan, } \\
\text { Province of } \\
\text { China }\end{array}$ & $67 \times 054$ & 94702 & $5.50 \%$ & Japan & 62726 & $83 \cdot 132$ & $4.50 \%$ \\
\hline Lapan & $70: 164$ & $82: 141$ & $4.80 \%$ & Netherlands & $52: 201$ & $63^{\circ} 968$ & $3.40 \%$ \\
\hline Malaysia & $57: 318$ & $67^{\prime \prime} 600$ & $3.90 \%$ & Mexico & $45^{\prime} 938$ & $57 \times 961$ & $3.10 \%$ \\
\hline Germany & 54743 & $64^{\prime} 652$ & $3.80 \%$ & $\begin{array}{l}\text { United } \\
\text { Kingdom }\end{array}$ & $47 \times 902$ & 51766 & $2.80 \%$ \\
\hline Netherlands & $53 \cdot 342$ & $61: 367$ & $3.60 \%$ & $\begin{array}{l}\text { Republic of } \\
\text { Korea }\end{array}$ & $41: 855$ & $50 \cdot 462$ & $2.70 \%$ \\
\hline Mexico & 49764 & $60 \cdot 159$ & $3.50 \%$ & $\begin{array}{l}\text { Taiwan, } \\
\text { Province of } \\
\text { China }\end{array}$ & $36: 339$ & $49 \cdot 164$ & $2.60 \%$ \\
\hline Thailand & $30: 164$ & $36^{\circ} 974$ & $2.10 \%$ & Malaysia & $37: 212$ & $49^{\circ} 052$ & $2.60 \%$ \\
\hline Hungary & 21.465 & $24: 218$ & $1.40 \%$ & France & $38: 233$ & $43^{\circ} 940$ & $2.40 \%$ \\
\hline $\begin{array}{l}\text { United } \\
\text { Kingdom }\end{array}$ & $23^{*} 400$ & $23^{\circ} 987$ & $1.40 \%$ & Italy & $25 \cdot 131$ & $35^{\circ} 979$ & $1.90 \%$ \\
\hline France & 19762 & $22: 584$ & $1.30 \%$ & Canada & $27^{\circ} 018$ & $32 \times 968$ & $1.80 \%$ \\
\hline $\begin{array}{l}\text { Czech } \\
\text { Republic }\end{array}$ & $16: 305$ & 19.835 & $1.20 \%$ & Thailand & $21^{\circ} 008$ & $25^{\prime} 867$ & $1.40 \%$ \\
\hline Philippines & $13^{\circ} 997$ & $18: 334$ & $1.10 \%$ & $\begin{array}{l}\text { Czech } \\
\text { Republic }\end{array}$ & 16.458 & $22 \times 357$ & $1.20 \%$ \\
\hline Sweden & 11788 & 15.477 & $0.90 \%$ & Spain & $18: 567$ & 21.085 & $1.10 \%$ \\
\hline Poland & $12: 808$ & $15 \times 172$ & $0.90 \%$ & Australia & 167699 & $20^{\circ} 087$ & $1.10 \%$ \\
\hline $\begin{array}{l}\text { World ICT } \\
\text { exports }\end{array}$ & $1.409 \cdot 523$ & $1 \cdot 721 \cdot 606$ & $100.00 \%$ & $\begin{array}{l}\text { World ICT } \\
\text { imports }\end{array}$ & $1 \cdot 505 \cdot 442$ & $1.861: 229$ & $100.00 \%$ \\
\hline
\end{tabular}

Source: UNCTADSTAT, http:/functadstat.unctad.orq/ReportFolders/reportFolders.aspx.

Table 2. Top destination of the world's 10 largest ICT goods exporters, 2010 (Millions of dollars and percentage)

\begin{tabular}{|c|c|c|c|c|}
\hline Exporter & $\begin{array}{c}\text { Top } \\
\text { destination }\end{array}$ & $\begin{array}{l}\text { Exports to } \\
\text { top } \\
\text { destination } \\
\text { (\$ million) }\end{array}$ & $\begin{array}{c}\text { Total } \\
\text { exports } \\
\text { (\$ million) }\end{array}$ & $\begin{array}{c}\text { Exports to top } \\
\text { destination as } \\
\text { a share of total } \\
\text { exports } \\
(\%)\end{array}$ \\
\hline China & $\begin{array}{l}\text { Hong Kong, } \\
\text { China }\end{array}$ & $110^{7} 772$ & 459.522 & $24 \%$ \\
\hline $\begin{array}{l}\text { Hong Kong. } \\
\text { China }\end{array}$ & China & $111^{\circ} 861$ & 176.964 & $63 \%$ \\
\hline $\begin{array}{l}\text { United } \\
\text { States }\end{array}$ & Mexico & 26.405 & 134.549 & $20 \%$ \\
\hline Singapore & $\begin{array}{l}\text { Hong Kong, } \\
\text { China }\end{array}$ & 23757 & $120 \cdot 806$ & $20 \%$ \\
\hline $\begin{array}{l}\text { Republic of } \\
\text { Korea }\end{array}$ & China & 26.937 & $99^{\prime} 884$ & $27 \%$ \\
\hline $\begin{array}{l}\text { Taiwan, } \\
\text { Province of } \\
\text { China }\end{array}$ & $\begin{array}{l}\text { Hong Kong, } \\
\text { China }\end{array}$ & 21.120 & 94702 & $22 \%$ \\
\hline Japan & China & $18 \times 930$ & 82141 & $23 \%$ \\
\hline Malaysia & China & $12^{\circ} 036$ & $67 \times 600$ & $18 \%$ \\
\hline Germany & Italy & 6.045 & $64^{\prime} 652$ & $9 \%$ \\
\hline Netherlands & Germany & $13: 318$ & $61: 367$ & $22 \%$ \\
\hline
\end{tabular}

Source:UNCTADSTAT, http:Junctadstat.unctad.orq/ReportFolders/reportFolders.aspx 


\subsubsection{China is the Most Dynamic Trading Economy in the World}

China is the most dynamic trading economy in the world (PWC, 2008). Jacques (2009) describes China as a growing economic power and central player in the twenty-first century. Although, China operates a centralised economic system, its international trade openness has increased considerably and the importance of state-owned enterprises has also reduced remarkably (Yang and Zheng 2005; Wen 2005; Tinsdale, 2009). From 1978 when China economic reforms began, the nation has witnessed substantial and steady growth (Table 3 ). The nation's international trade openness also grown remarkably (Tables 4 and 5), and over $40 \%$ of China's GDP is contributed by privately owned enterprises (Tisdell 2007; Qian and Wu, 2008; World Bank, 2013). China rapid economic development and dynamic trading economy are tenable reasons for conducting trade with China.

Table 3: China’s Average Annual Real GDP Growth: 1979-2012

\begin{tabular}{|c|c|c|c|}
\hline Year & Real Growth Rate $(\%)$ & Year & Real Growth Rate $(\%)$ \\
\hline 1979 & 7.6 & 1996 & 10 \\
\hline 1980 & 7.9 & 1997 & 9.3 \\
\hline 1981 & 5.3 & 1998 & 7.8 \\
\hline 1982 & 9.0 & 1999 & 8.4 \\
\hline 1983 & 10.9 & 2000 & 8.3 \\
\hline 1984 & 15.2 & 2001 & 9.1 \\
\hline 1985 & 13.5 & 2002 & 10.0 \\
\hline 1986 & 8.9 & 2003 & 10.1 \\
\hline 1987 & 11.6 & 2004 & 11.3 \\
\hline 1988 & 11.3 & 2005 & 12.7 \\
\hline 1989 & 4.1 & 2006 & 14.2 \\
\hline 1990 & 3.8 & 2007 & 9.6 \\
\hline 1991 & 9.2 & 2008 & 9.2 \\
\hline 1992 & 14.2 & 2009 & 10.4 \\
\hline 1993 & 13.9 & 2010 & 8.1 \\
\hline 1994 & 13.1 & 2011 & \\
\hline 1995 & 10.9 & $2012-$ First Quarter & \\
\hline
\end{tabular}

Source: Economist Intelligence Unit, based on official Chinese government data. $* 2012$ data are year-on-year

Table 4: China's Trade with the World, 2001-2010 (\$ billion)

\begin{tabular}{|crrrrrrrrrr|}
\hline & 2001 & 2002 & 2003 & 2004 & 2005 & 2006 & 2007 & 2008 & 2009 & 2010 \\
Exports & 266.1 & 325.6 & 438.2 & 593.3 & 762.0 & 968.9 & $1,217.8$ & $1,430.7$ & $1,201.6$ & $1,577.9$ \\
$\%$ change* & 6.8 & 22.4 & 34.6 & 35.4 & 28.4 & 27.2 & 25.7 & 17.5 & -16.0 & 31.3 \\
Imports & 243.6 & 295.2 & 412.8 & 561.2 & 660.0 & 791.5 & 956.0 & $1,132.6$ & $1,005.9$ & $1,394.8$ \\
$\%$ change* & 8.2 & 21.2 & 39.8 & 35.9 & 17.6 & 19.9 & 20.8 & 18.5 & -11.2 & 38.7
\end{tabular}




\begin{tabular}{crrrrrrrrrr} 
Total & 509.7 & 620.8 & 851.0 & $1,154.6$ & $1,421.9$ & $1,760.4$ & $2,173.7$ & $2,563.3$ & $2,207.5$ & $2,972.8$ \\
\% change* & 7.5 & 21.8 & 37.1 & 35.7 & 23.2 & 23.8 & 23.5 & 17.9 & -13.9 & 34.7 \\
Balance & 22.6 & 30.4 & 25.5 & 32.1 & 102.0 & 177.5 & 261.8 & 298.1 & 195.7 & 183.1 \\
\hline
\end{tabular}

Source: National Bureau of Statistics of China, 2012

NOTES: *Calculated by US-China Business Council (USCBC).

Table 5: China's Top Trade Partners, 2010 (\$ billion)

\begin{tabular}{|llcc|}
\hline Rank & Country/Region & Volume & \% change over 2009 \\
1 & United States & 385.3 & 29.2 \\
2 & Japan & 297.8 & 30.2 \\
3 & Hong Kong & 230.6 & 31.8 \\
4 & South Korea & 207.2 & 32.6 \\
5 & Taiwan & 145.4 & 36.9 \\
6 & Germany & 142.4 & 34.8 \\
7 & Australia & 88.1 & 46.5 \\
8 & Malaysia & 74.2 & 42.8 \\
9 & Brazil & 62.5 & 47.5 \\
10 & India & 61.8 & 42.4 \\
\hline
\end{tabular}

Source: PRC General Administration of Customs, China's Customs Statistics

\subsubsection{China Business and Economic Growth}

China business and economic growth have improved considerably; hence it offers immersed opportunities for foreign investors, including XYZ International. China is one of the world's largest and fastest growing marketplaces. It is a home for the world's emerging global companies (PWC, 2008). Whilst the global foreign direct investment (FDI) flows continued declining in the third quarter of 2012; China remained the first FDI destination for third consecutive quarter in 2012 (OECD, 2013). China attracted the largest share of global FDI flows with USD 170 billion (Table 6) during the period January - September 2012 (OECD, 2013).

Table 6: China's Foreign Direct Investment Inflows (Units: USD Billion)

\begin{tabular}{|c|c|c|c|c|c|c|c|}
\hline \multicolumn{5}{|c|}{ Annual } & \multicolumn{3}{c|}{ Quarterly } \\
\hline 2007 & 2008 & 2009 & 2010 & 2011 & Q1 2012 & Q2 2012 & Q3 2012 \\
\hline 160.1 & 175.1 & 114.2 & 185 & 228.6 & 63.3 & 54.4 & 52.2 \\
\hline
\end{tabular}

Source: OECD (2013)

4.9.4 China is the Second Largest Economy and Biggest Exporter in the World

China growth in 2011 was above 9.3\% (World Bank, 2013) and is the biggest exporter in the 
world (CIA, 2012). China WTO membership in 2001 provided China a platform to entrenched itself as a world's biggest exporter (Tables 7, 8 and 9) and second largest economy in the world (EU, 2012). Table 4 shows the breakdown of items exported by China in 2010.

Table 7: Country comparison - Export (\$) in Billion as at 2011

\begin{tabular}{|c|l|r|}
\hline Rank & Country & Exports \\
\hline 1 & China & $2,050.00$ \\
\hline 2 & United States & $1,612.00$ \\
\hline 3 & Germany & $1,492.00$ \\
\hline 4 & Japan & 792.90 \\
\hline 5 & France & 567.50 \\
\hline 6 & Netherland & 556.50 \\
\hline 7 & South Korea & 552.60 \\
\hline 8 & Russia & 530.70 \\
\hline 9 & Italy & 483.30 \\
\hline 10 & Canada & 481.70 \\
\hline
\end{tabular}

Source: CIA, 2012

Table 8: China's Top Exports, 2010 (\$ billion)

\begin{tabular}{|c|c|c|c|}
\hline HS & Commodity description & Volume & $\%$ change over 2009 \\
\hline 85 & Electrical machinery and equipment & 388.8 & 29.1 \\
\hline 84 & Power generation equipment & 309.8 & 31.4 \\
\hline 61,62 & Apparel & $121.1 *$ & $20.5^{*}$ \\
\hline 72,73 & Iron and steel & $68.1^{*}$ & $44.1^{*}$ \\
\hline 90 & Optics and medical equipment & 52.1 & 34.0 \\
\hline 94 & Furniture & 50.6 & 30.0 \\
\hline 28,29 & Inorganic and organic chemicals & $43.2 *$ & $34.9 *$ \\
\hline 89 & Ships and boats & 40.3 & 42.1 \\
\hline 87 & Vehicles, excluding rail & 38.4 & 37.5 \\
\hline 64 & Footwear & 35.6 & 27.1 \\
\hline
\end{tabular}

Source: PRC General Administration of Customs, China's Customs Statistics

Calculated by USCBC

Table 9: China's Top Export Destinations, 2010 (\$ billion)

\begin{tabular}{|l|l|r|r|}
\hline Rank & Country/region & \multicolumn{1}{|l|}{ Volume } & \% change over 2009 \\
\hline 1 & United States & 283.3 & 28.3 \\
\hline 2 & Hong Kong & 218.3 & 31.3 \\
\hline
\end{tabular}




\begin{tabular}{|l|l|c|c|}
\hline 3 & Japan & 121.1 & 23.7 \\
\hline 4 & South Korea & 68.8 & 28.1 \\
\hline 5 & Germany & 68.0 & 36.3 \\
\hline 6 & The Netherlands & 49.7 & 35.5 \\
\hline 7 & India & 40.9 & 38.0 \\
\hline 8 & United Kingdom & 38.8 & 24.0 \\
\hline 9 & Singapore & 32.3 & 7.6 \\
\hline 10 & Italy & 31.1 & 53.8 \\
\hline
\end{tabular}

Source: PRC General Administration of Customs, China's Customs Statistics

\subsubsection{Importance of Foreign Owned and Private Firms in China}

Although several industries are largely state-owned, foreign owned and private companies are rapidly gaining importance in the Chinese economy. Chinese transnational corporations (TNCs) play active role in a number of industries and the wide spread of their FDI projects over a large number of host economies have raised awareness of their home country as a source of investment. The United Nations Conference on Trade and Development (UNCTAD) World Investment Prospects Survey 2012-2014 provides an outlook on future trends in foreign direct investment (FDI) by the largest TNCs. China led the list with 62 per cent of respondents selecting it (Table 10). Essentially, this is largely due to the rapid increase of its outward FDI in recent years - 41 and 57 per cent in 2009 and 2010 respectively (UNCTAD, 2009; 2010).

Table 10: TNCs' top prospective host economies, 2012-2014

(Percentage of respondents selecting economy as a top destination)

\begin{tabular}{|c|c|c|}
\hline Country & \% of Responses & Ranking \\
\hline China & 62 & 1 \\
\hline United States & 61 & 2 \\
\hline Germany & 41 & 3 \\
\hline United Kingdom & 40 & 4 \\
\hline France & 27 & 5 \\
\hline Japan & 22 & 6 \\
\hline India & 21 & 7 \\
\hline Spain & 17 & 8 \\
\hline Canada & 17 & 9 \\
\hline United Arab Emirates & 11 & 10 \\
\hline Brazil & 11 & 11 \\
\hline
\end{tabular}

Source: UNCTAD Survey World Investment Prospects 2012-2014 


\subsubsection{Chinese Government Incentives to Attract International Investors}

The Chinese government encourages and attracts international investors to invest in China. Notwithstanding considerable bureaucracy, the Chinese government is making efforts to promote foreign investment. The Chinese government has been proactive in removing tariff and non-tariff barriers for trade in goods through the negotiation and implementation of regional free trade agreements (PWC, 2008). Furthermore, China has passed an Anti-Monopoly Law (AML) which regulate competition effective August 2008 (Tian, 2010; Chin, 2012). China's Anti-Monopoly Law (AML) is the first anti-monopoly law in China. The AML has been described as an economic constitution and milestone of China's efforts in promoting a fair competition market and cracking down on monopoly activities (Tian, 2010). However, foreign businesses in China, including XYZ International, need to consider the immediate impact of the new law on their businesses.

\subsubsection{China Huge Population}

China's huge population provides international firms with a great pool of low-wage workers, enabling mass-market factories and lower-cost production platforms to produce for both the export market and the growing Chinese market (Meredith, 2007, Wu, 2008; Czinkota et al., 2011). With its population of 1.3 billion, China has low production costs and a higher supply of cheap labour. China has the highest labour force of about 795.4 million by the end of 2012 (CIA, 2012). Its labour force by occupation in 2012 was: agriculture - 34.8\%; industry - 29.5\%; and services $-35.7 \%$ (CIA, 2012). This is one of the major reasons for supporting trade with China, as reduced cost of production (particularly low-cost labour) enhances profitability. This is beneficial to international investors as China's huge population, together with the nation's export-friendly infrastructures, facilitates lower-cost production platforms. However, it has been observed that China's labour force may have already reached its peak in 2011 (Rozelle $e t$ $a l ., 2008)$. Furthermore, most rural youth in the 16-20 age brackets are already working off the farm; hence, China's rural-to-urban migration may reduce because the rural young people are highly Mobile (Hongbin et al., 2012).

\subsubsection{China Political Stability and Rapid Economic Growth}

Political stability and rapid economic growth are other considerations for conducting trade with China. China's political and social landscape is stable after the nation's three decades of reform and opening-up. China's economy, largely closed to international trade before December 1978, has changed from a centrally planned system to a more market-oriented that has a rapidly growing private sector (Tisdell, 2009). This is obvious form the chronology of events and the implication of the events associated with the formulation of China's development policies in the last three decades (Table 11).

Table 11: Chronological events of China's development policies in the last three decades

\begin{tabular}{|l|l|}
\hline Time & Event \\
\hline Jan 1976 & Premier Zhou Enlai dies. \\
\hline Sept 1977 & Chairman Mao Zedong dies. Hua Guafeng becomes Chairman of the CCP and subsequently Deng \\
\hline
\end{tabular}




\begin{tabular}{|c|c|}
\hline & Xiaoping returns from political exile. \\
\hline Dec. 1978 & $\begin{array}{l}\text { Increasing CCP support for Deng Xiaoping's reformist agenda culminates in its basic acceptance } \\
\text { by the } 11 \text { th Central Committee of the CCP. It was argued that the reforms should begin with } \\
\text { agriculture. }\end{array}$ \\
\hline 1979 & $\begin{array}{l}\text { Deng Xiaoping becomes Chairman of the Military Commission. He criticises dogmatic approaches } \\
\text { to policy and favours a pragmatic approach. }\end{array}$ \\
\hline 1980 & Hua Guofeng steps down as Chairman of CCP. \\
\hline Mid-1981 & $\begin{array}{l}\text { Under the influence of Deng Xiaoping, the CPC stresses that China's policies for modernisation } \\
\text { must be realistically based, systematic and staged, and take account of Chinese conditions. }\end{array}$ \\
\hline 1984 & $\begin{array}{l}\text { The CCP decides that the economic reforms commenced in agriculture should be extended to the } \\
\text { whole economy. An end to the privileged position of state enterprises is signalled. Increasing } \\
\text { emphasis occurs on greater economic openness as an instrument of development policy. }\end{array}$ \\
\hline 1989 & $\begin{array}{l}\text { Chairman Jiang Zemin confirms the direction of China's development policies, such as extension } \\
\text { of the market system and greater economic openness as well as measures to limit population } \\
\text { growth. He saw the need for China to improve its science and technology policy because as China } \\
\text { catches up with the rest of the world's technology; it will need to do more to advance its own } \\
\text { scientific and technological improvements. }\end{array}$ \\
\hline 2002 & $\begin{array}{l}\text { Jiang Zemin in his report to the } 16 \text { th Congress of the CCP re-affirms China's policies for economic } \\
\text { development but expressed concern about growing economic inequality in China. Given changed } \\
\text { economic conditions in China, it seemed that Deng Xiaoping's principle of payment according to } \\
\text { work (expounded in 1978) was going to be modified. China's rise as a major global economy was } \\
\text { boosted by its WTO membership in 2001, which made it reform and open up its economy. This } \\
\text { provided a platform for the nation to establish itself as a major global trader and exporter. }\end{array}$ \\
\hline 2007 & $\begin{array}{l}\text { Chairman Hu Jintao in his report to the } 17 \text { th Congress of the CCP then confirmed support for } \\
\text { continuing earlier economic reforms but also indicated that policy must pay more attention to } \\
\text { income inequality, approaching technological (and similar) barriers to China's continuing } \\
\text { development, and environmental and energy issues. }\end{array}$ \\
\hline 2008 & $\begin{array}{l}\text { China faced the challenge of the global economic crises and formulated policies to weather the } \\
\text { economic storm. This has been described as 'China's greatest [economic] crisis since its reforms } \\
30 \text { years ago'. }\end{array}$ \\
\hline $\begin{array}{ll}2009 & \text { To } \\
2011 & \end{array}$ & $\begin{array}{l}\text { Signs of recovery of economic activity in China as a result of Government intervention. China is } \\
\text { the second largest economy and biggest exporter in the world. it growth in } 2011 \text { was above } 9 \% \text {, } \\
\text { and international estimates predict China may be on track to become the world's biggest economy } \\
\text { within the next 5-10 years, with an internal market of } 1.39 \text { billion potential consumers by the end } \\
\text { of } 2015 \text { (EU, 2012). This provided a platform for China to establish itself as a major global trader } \\
\text { and the world's biggest exporter. About half of China's exports are produced by foreign invested } \\
\text { companies. China attracted the largest share of global FDI flows with USD } 170 \text { billion between } \\
\text { January and September } 2012 \text { (OECD, 2013). Similarly, the UNCTAD Survey World Investment } \\
\text { Prospects } 2012-2014 \text { provides an outlook on future trends in foreign direct investment (FDI) by } \\
\text { the largest TNCs; China led the list with } 62 \text { per cent of respondents selecting it. }\end{array}$ \\
\hline
\end{tabular}

China's Development Policies in the Last 30 Years - Adapted from: Tisdell 2009

\section{Conclusion}

The emergence of capitalism into China enhanced international firms' investment in the country. This resulted to creation of a production base to explore the inexpensive factors of 
production, particularly low-cost labour. Hence, the Chinese production flourished through improvements in production facilities, access to ports, skilled labour, and export friendly infrastructure (Czinkota et al., 2011). Mutual awareness of cultural references is essential in international business as levels of formality vary greatly among cultures. The study has examined cultural awareness as a form of risk management in international business, using China as a case study. The study used 'XYZ International' as a hypothetical international business, with western cultural background, which operates in China market. The study explored international trade and global organisations; considered barriers to international business; justified cultural awareness as a form of risk management in international business; highlighted Chinese business culture; outlined the impact of culture on negotiation; appraised Chinese business culture and its impact in the Chinese market; and presented arguments to support conducting trade with China. The study has shown that mutual awareness of cultural references is essential in international business, and levels of formality vary greatly among cultures. The implication for practice is that culture induces each country societal prevailing life-styles because culture and life-style influence patterns of consumption, manufacturing, agriculture, service, distribution and investment.

\section{References}

Adler, N. J. (2008). International-business scholarship: Contributing to a broader definition of success. In: J. J. J. Boddewyn (Ed.) International Business Scholarship: AIB Fellows on the First 50 Years and Beyond Research in Global Strategic Management (Volume 14) (pp. 327-337), Emerald Group Publishing Limited.

Central Intelligence Agency (2012). World Factbook - Country comparison: Export. CIA Accessed 13 April 2013.

Chen, M. (1995). Asian management systems: Chinese, Japanese and Korean styles of business. London, Routledge.

Chin, Y. W. (2012). Merger control under China's Anti-Monopoly Law. Legal law for China investments E.4.2.

CASSTC (2009). Chinese Academy of Science, Science \& Technology in China: A Roadmap to 2050. China: Science Press.

Chow, G. C. (2004). Economic reform and growth in China. Annals of Economics and Finance, 5, pp. 127-152.

Chu, C. N. (1991). The Asian mind game. New York: NY, Rawson Associates.

Clifton, J. (2004). Culture and international business. New York, NY: Blackwell.

Czinkota, M. R., Ronkainen, I. A., \& Moffett, M. H. (2011). International business ( $8^{\text {th }}$ ed.). Danvers, MA: John Wiley.

Damodaran, A. (2008). Strategic risk taking: A framework for risk management. Upper Saddle River, New Jersey: Prentice Hall. 


\section{Macrothink}

Business and Economic Research ISSN 2162-4860 2014, Vol. 4, No. 1

Dunfee, T. W., \& Warrant, D. E. (2001). Is Guanxi ethical? A normative analysis of doing business in China. Journal of Business Ethics, 32, pp. 191-204. http://dx.doi.org/10.1023/A:1010766721683

Emerson, N. (2007). The social dimension of international business. Beverly Hill: Sage.

European Union (2012). Facts and figures on EU-China trade: Did you know? 13 April 2013.

Fadun, O. S. (2013). Risk management and risk management failure: Lessons for business enterprises in Nigeria. International Journal of Academic Research in Business and Social Sciences, 3(2), 225-239.

Fan, D., Nyland, C., \& Zhu, C. J. (2009). Integration-responsiveness framework for Chinese MNCs: An area for future study. Working Paper 5/09: Monash University, Department of Management.

Fang, T. (1999). Chinese business negotiation style. Thousand Oaks, CA: Sage.

Fang, T. (2001). Culture as a driving force for inter-firm adaptation: A Chinese case. Industrial Marketing Management, p. 30. http://dx.doi.org/10.1016/S0019-8501(99)00088-7

Fang, T. (2006). Negotiation: The Chinese style. Journal of Business \& Industrial Marketing, 21(1), 50-60. http://dx.doi.org/10.1108/08858620610643175

Faure, G. O. (1998). Negotiation: The Chinese concept. Negotiation Journal, 14(2), 137-148. http://dx.doi.org/10.1111/j.1571-9979.1998.tb00154.x

Gangopadhyay, P., \& Chatterji, M. (2005). Economics of globalisation. London: Ashgate.

Ghauri, P., \& Fang, T. (2001). Negotiating with the Chinese: A social-cultural analysis. Journal of World Business, 36(3), 303-325. http://dx.doi.org/10.1016/S1090-9516(01)00057-8

Gibson, J. L., Ivancevich, J. M., Donnelly, J. H., \& Konopaske, R. (2012). Organisations: Behaviour, structure, processes $\left(14^{\text {th }}\right.$ ed.). New York, NY: McGraw-Hill Irwin.

Goodrich, A. (2005). The dynamics of global business. Chicago: Gift Book Publishers.

Graham, J. L., \& Lam, N. M. (2003). The Chinese negotiation. Harvard Business Review. 12 April 2013.

Guillen, M. F. (2001). Is globalisation civilising, destructive or feeble? A critique of five key debates in the social science literature. Annual Review of Sociology, 27, 235-260. http://dx.doi.org/10.1146/annurev.soc.27.1.235

Hillson, D. A., \& Murray-Webster, R. (2011). Using risk appetite and risk attitude to support appropriate risk taking: A new taxonomy and model. Journal of Project, Program \& Portfolio Management, 2(1), 29-46.

Hofstede, G. (1980). Culture's consequences: International differences in work-related values. Newbury Park, California: Sage.

Hofstede, G. (2011). Dimensionalizing Cultures: The Hofstede Model in Context. [Online] 
Readings in Psychology and Culture, Unit 2. 14 April 2013. http://dx.doi.org/10.9707/2307-0919.1014

Hongbin, Li., Lei, L., Wu, B., \& Xiong, Y. (2012). The end of cheap Chinese labour. Journal of Economic Perspectives, 26(4), 57-74. http://dx.doi.org/10.1257/jep.26.4.57

Horwitz, F., Hemmant, R., \& Rademeyer, C. (2008). Chinese business negotiations:South African firm experiences and perspectives. South African Journal of Business Management, 39(1), 1-13.

Hubbard, D. W. (2009). The failure of management: Why it's broken and how to fix it. Hoboken, New Jersey: John Wiley.

Hummel, D. P. (2012). Understanding the importance of culture in global business. Oracle 7 March 2013.

Infoplease (2012). Population density per square mile of countries. 6 April 2013.

Internet World Stats [IWS] (2013). The world population and the top ten countries with the highest population.

International Monetary Fund (2000). Globalisation: Threat or Opportunity? Washington D.C: IMF.

Irrgang, B. (2007). Technology transfer and modernization: what can philosophers of technology contribute? December Article no. 1. Accessed 12 April 2013.

Jacques, M. (2009). When China rules the World: The rise of the middle kingdom and the end of the Western World ( $2^{\text {nd }}$ ed.). London: Penguin.

Jin, J. (2012). Science \& technology and modernisation. Modernisation Science Newsletter, 2(2), 1-14.

Jones, G., \& George, J. (2013). Essentials of contemporary management (5th ed.). New York, NY: McGraw-Hill Irwin.

Lechner, F. J. (2012). The globalisation reader (4 ${ }^{\text {th }}$ ed.). Maiden, MA: John Wiley.

Leung, K., Bhagat, R. S., Buchan, N. R., Erez, M., \& Gibson, C. B. (2005). Culture and international business: recent advances and their implications for future research. Journal of International Business Studies, 36, 357-378. http://dx.doi.org/10.1057/palgrave.jibs.8400150

Meredith, R. (2007). The elephant and the dragon: The rise of India and China and what It means for all of us. New York, NY: W. W. Norton.

Michie, J. (2011). The handbook of globalisation ( $2^{\text {nd }}$ ed.). Northampton, MA: Edward Elgar. http://dx.doi.org/10.4337/9780857931443

Miles, M. (2003). Negotiating with the Chinese: Lessons from the Field. Journal of Applied Behavioural Science, 39(4), 453-472. http://dx.doi.org/10.1177/0021886303260547

Morden, T. (2007). Principles of strategic management. Aldershot, London: Ashgate. 


\section{Macrothink}

Business and Economic Research ISSN 2162-4860 2014, Vol. 4, No. 1

Mun, K. C. (1990). The competition model of Sun Tzu's Art of War. In: H. Kuang, (Ed.), Encyclopedia of modern marketing in Chinese (pp. 930-935). Beijing, Economics and Management Press.

Nadeau, J., \& Casselman, M. (2008). Competitive advantage with new product development: Implications for life cycle theory. Journal of Strategic Marketing, 16(5), 401-411.http://dx.doi.org/10.1080/09652540802480894

OECD (2013). GDP in figures. 13 April 2013.

Palk, Y., \& Sohn, J. H. D. (2004). Striking a balance between global integration and local responsiveness: The case of Toshiba Corporation in redefining regional headquarters' role. Organizational Analysis, 12(4), 347-359.

PricewaterhouseCoopers (2013). Doing business and investing in China. Beijing: PWC. http://download.pwc.com/ie/pubs/2013_doing_business_and_investing_in_china.pdf

Qian, Y., \& Wu, J. (2008). Transformation in China. In: J. Kornai, L. Máltyás and G. Roland (Eds.), Institutional change and economic behaviour (pp. 38-63). Basingstoke, London: Palgrave Macmillan.

Quanyu, H., Leonard, J., \& Tong, C. (1997). Business decision making in China. Binghamton, NY: International Business Press.

Rath, S. P. (2012). Legislation effectiveness in current economic environment towards global integration of organizations. International Journal of Social Science Tomorrow, 1(9), pp. 1-6.

Ritzer, G. (2011). Globalisation: the essentials. Maiden, MA: John Wiley.

Rozelle, S. D., Huang, J., Zhang, L., \& Li, X. (2008). China's labour transition and future educational challenges. Stanford University.

Salacuse, J. W. (2004). Negotiating: The top ten ways that culture can affect your negotiation. Ivey Business Journal, September/October.

Sebenius, J. K., \& Qian, C. J. (2008). Cultural notes on Chinese negotiating behaviour. Working Paper 09-076: Harvard Business School.

Stutz, F. P., \& Warf, B. (2011). The world economy: Resources, location, trade and development $\left(6^{\text {th }}\right.$ ed.). Upper Saddle River: Pearson.

Sun T. (1982). The art of war (translated by Samuel B. Griffith). London, Oxford University.

Tian, X. W. (2007). Managing international business in China. Cambridge: Cambridge University. http://dx.doi.org/10.1017/CBO9780511810558

Tian, Y. (2010). The impacts of the Chinese anti-monopoly law on IP commercialisation in china and general strategies for technology-driven companies and future regulators. Duke Law \& Technology Review, 4, 1-23.

Tibbs, H. (2011). Changing cultural values and the transition to sustainability. Journal of 
Futures Studies, 15(3), 13-32.

Tisdell, C. A. (2007). Economic and business relations between China and Australia: Insights into China's global economic footprint. In: P. Basu, G. O’Neill, and A. Travaglione (Eds.). Engagement and change (pp. 11-24). Brisbane: Australian Academic Publishers.

Tisdell, C. (2009). Economic reform and openness in China: China's development policies in the last 30 years. Economic Analysis \& Policy, 39(2), pp. 271-294.

Tsang, E. W. K. (2004). Toward a scientific inquiry into superstitious business decision-making. Organisation Studies, 25(6), 923-946. http://dx.doi.org/10.1177/0170840604042405

Tung, R. L. (1994). Strategic management thought in East Asia. Organisational Dynamics, 22(4), 55-65. http://dx.doi.org/10.1016/0090-2616(94)90078-7

United Nations Development Programme (2001). Human development reports 2001: Making new technologies work for human development. New York, NY: Oxford University.

United Nation Conference on Trade and Development (2012). UNCTAD statistics show china now the world's largest exporter and importer of ICT products. UNCTAD 11 April 2013.

United Nation Conference on Trade and Development (2009). World investment prospects survey, 2009-2011. New York and Geneva: United Nations - UNCTAD.

UNCTAD (2010). World investment prospects survey, 2010-2012. New York and Geneva: United Nations.

UNCTAD (2012). World investment prospects survey 2012-2014. New York and Geneva: United Nations.

Von Senger, H. (2006). The 36 stratagems for business. Marshall Cavendish.

Yang, R., \& Zhang, Y. (2005). Globalisation and China's reform of state-owned enterprises (SOEs). In: C. Tisdell (Ed.), Globalisation and world economic policies (pp. 374-387). New Delhi, India: Serials Publications.

Guest, L., Notman, D., \& Wilson, J. (2007). The world of business (5 $5^{\text {th }}$ ed.). Canada: Nelson Education.

Wen, J. J. (2005). Can globalisation save SOEs in China? In: C. Tisdell (Ed.), Globalisation and world economic policies (pp. 388-401). New Delhi, India: Serials Publications.

Wen-Cheng, W., Chien-Hung, L., and Ying-Chien, C. (2011). Types of competitive advantage and analysis. International Journal of Business and Management, 6(5), 100-104. http://dx.doi.org/10.5539/ijbm.v6n5p100

World Bank (2013). GDP growth (Annual \%). 13 April 2013.

$\mathrm{Wu}, \mathrm{J}$. (2008). An analysis of business challenges faced by foreign multinationals operating the Chinese market. International Journal of Business and Management, 3(12), pp. 169-174.

World Trade Organisation (2014). What is the WTO. 23 July 2013 


\section{Copyright Disclaimer}

Copyright reserved by the author(s).

This article is an open-access article distributed under the terms and conditions of the Creative Commons Attribution license (http://creativecommons.org/licenses/by/3.0/). 